Ліда Нанівська

Хмельницька гуманітарно-педагогічна академія ORCID ID 0000-0002-8922-8241

DOI 10.24139/2312-5993/2020.10/177-188

\title{
СТРУКТУРНО-ФУНКЦІОНАЛЬНА МОДЕЛЬ ФОРМУВАННЯ КОМУНІКАЦІЙНОӦ КОМПЕТЕНТНОСТІ МАЙБУТНІХ ОФІЦЕРІВ ІНЖЕНЕРНИХ ВІЙСЬК: АНАЛІЗ РЕЗУЛЬТАТІВ
}

у статті розглянуто теоретичні питання побудови структурнофункціональної моделі формування комунікативної компетентності майбутніх офріцерів інженерних військ у процесі іншомовної підготовки. Використано дані психолого-педагогічних джерел та проведених наукових досліджень щодо визначеної теми. Це дало можливість виокремити складники структурно-функціональної моделі: змістовно-цільовий; процесуальний; результативний.

Експериментальна робота з перевірки дієвості структурно-функцінальної моделі в освітній процес вищих військових закладів здійснювалась у три етапи $i$ охопила такі дисципліни освітньої програми підготовки курсантів: «Військовоспеціальна мовна підготовка» та «/ноземна мова за профресійним спрямуванням».

Ключові слова: іншомовна підготовка, майбутні офріцери, модель, компоненти, організаційно-педагогічні умови, методи, метод проєктів, ситуативний метод.

Постановка проблеми. Комунікативна компетентність $€$ однією із складових професійної підготовки майбутніх офіцерів. У нашому баченні одним із шляхів їі розвитку $\epsilon$ процес іншомовної підготовки. Сучасний офіцер повинен широко і свідомо використовувати знання, набуті в закладі освіти, володіти професійною іншомовною підготовкою, що дозволяє швидко адаптуватися до сучасних умов та бути здатним до самореалізації та самоосвіти у своїй професійній діяльності.

Щоб спрогнозувати будь-який процес, можна використовувати метод моделювання. Він $є$ популярний у всіх без винятку науках і на всіх етапах наукового дослідження. Це можна пояснити тим, що вдається зробити будь-яке явище дійсності доступним для пізнання.

Аналіз актуальних досліджень. Теоретичні підходи до процесу моделювання ми знайшли у працях Ю. Бабанського, С.Гончаренка, Р. Горбатюка Т. Ільїної, Н. Новіка, О. Пєхоти, Л.Фрідмана, В. Штоффа та ін.

Метод моделювання, базований на системному підході, обґрунтувала низка науковців М. Анісімов, Т. Гуменюк, О. Дахін, Н. Кушнаренко, Є. Лодатко, $€$. Павлютенков, Р. Серветником, О. Шапран та ін.

Метою статті $\epsilon$ висвітлення теоретичних питань побудови структурно-функціональної моделі формування комунікативної 
компетентності майбутніх офіцерів інженерних військ у процесі іншомовної підготовки.

Методи дослідження. У проведеному дослідженні було використано дані психолого-педагогічних джерел та проведених наукових досліджень щодо формування комунікативної компетентності майбутніх офіцерів інженерних військ у процесі іншомовної підготовки.

Застосовано порівняльний метод аналізу. Це дало можливість виокремити складники структурно-функціональної моделі формування комунікативної компетентності майбутніх офіцерів інженерних військ у процесі іншомовної підготовки.

Виклад основного матеріалу. Розробка структурно-функціональної моделі формування комунікативної компетентності майбутніх офіцерів інженерних військ у процесі іншомовної підготовки була одним із ключових завдань нашого дослідження. Під моделюванням у науці розуміється процес побудови, вивчення й застосування моделей, що тісно пов'язано з такими категоріями, як абстракція, аналогія, гіпотеза та інші. Процес моделювання включає і побудову абстракцій, і умовиводи за аналогією, і конструювання наукових гіпотез.

Моделювання розглядаємо як загальнонауковий метод дослідження, сутність якого полягає в побудові та дослідженні особливих об'єктів моделей та інших об'єктів - оригіналів чи прототипів. У філософському словнику (Філософський енциклопедичний словник, 2002), зазначено, що моделювання доцільно розглядати як метод дослідження об'єктів пізнання, що передбачає побудову й вивчення моделей предметів і явищ.

Модель у певному сенсі відображає (відтворює, моделює, описує, імітує) деякі цікаві для дослідника риси об'єкта. У перекладі з французької «модель» означає «аналог», «схема», «структура» тощо. Модель у латинській мові - образ, зменшений варіант, тобто спрощений опис складного явища або процесу. Виходячи з цього, модель - це штучно створений об'єкт у вигляді схеми, конструкцій, знакових форм або формул, який, будучи подібний до досліджуваного об'єкта (або явища), відображає й відтворює в простому і абстрактному вигляді структуру досліджуваного процесу або явища (Ягупов, 2003).

На думку О. Єлькіна, «узагальнення наявних у науковій літературі визначень поняття «модель» дозволяє встановити, що їх автори називають ознаки, властиві моделям: штучно створений зразок; структура, яка відтворює частину дійсності в спрощеному вигляді; наочна форма 
відображення оригіналу, конкретний образ об'єкта, у якому відображаються реальні або передбачувані властивості» (Елькина, 2007).

у нашому дослідженні експериментальна робота з формування комунікативної компетентності майбутніх офіцерів інженерних військ у процесі іншомовної підготовки побудована таким чином, що модель висловлює зміст пояснювальних явищ у спрощених структурах об'єктів, за допомогою яких модель з'ясовує зв'язки і відносини об'єктів та явищ. Таким чином, основною функцією педагогічної моделі $€$ відображення й відтворення в більш простому вигляді структури багатофакторного явища, безпосереднє розгляд якої дає нові знання про об'єкт вивчення (Панфілов, 2005).

Так, за Ю. Кулаковим, А. Коганом та А. Пироговим (Кулаков та ін., 2011), моделювання - це процес створення ієрархій моделей, у яких деяка реально існуюча система моделюється в різних аспектах і різними засобами. Посилаючись на А. Москаленко, серед основних аспектів застосування нашого моделювання виділяємо наступні (Москаленко, 2001):

- гносеологічний аспект: модель грає роль проміжного об'єкта в процесі пізнання педагогічного явища;

- загальнопедагогічний аспект, який дозволяє оцінювати зв'язки й відносини між характеристиками стану різних елементів навчальновиховного процесу на різних рівнях їх опису та вивчення;

- психологічний, який дозволяє вести опис різних сторін навчальної та педагогічної діяльності і виявляти на цій основі психолого-педагогічні закономірності.

До розробки педагогічних моделей навчання науковці висувають певні специфічні вимоги:

- концептуальність: модель повинна спиратися на наукову концепцію, до складу якої входять філософське, психологічне, дидактичне, соціально-педагогічне обґрунтування досягнення освітніх цілей;

- системність: модель повинна мати всі ознаки системи: логіку процесу, взаємозв'язок усіх його складових, цілісність;

- керованість: передбачає можливість керування, поетапної діагностики навчального процесу, зміну засобів і методів для поліпшення результатів;

- ефективність: модель повинна бути оптимальною за параметрами «результат/витрати», гарантовано досягати прийнятих стандартів навчання та виховання;

- відтворюваність: передбачає можливість переносу моделі для застосування іншими закладами освіти (Елькина, 2007). 
Модель - інструмент пізнання, за допомогою якого дослідник вивчає те, що його цікавить. Таким чином, під моделлю розуміють подумки представлений об'єкт (або опис об'єкта, системи), який у процесі дослідження за певних умов заміщає об'єкт-оригінал (для вивчення оригіналу або відтворення його будь-яких властивостей) так, що його безпосереднє вивчення дає нові знання про об'єкт-оригінал (у результаті перенесення однієї структури на іншу). Під час створення моделі формування комунікативної компетентності майбутніх офіцерів інженерних військ у процесі іншомовної підготовки ми керувалися такими вимогами:

- по-перше, коректність моделі, що має на увазі оптимальність співвідношення взаємодіючих у моделі елементів, що відбивають реальний модельований об'єкт;

- по-друге, вона дає конкретний опис основ функціонування системи й відповідає реальним властивостям та взаємозв'язкам елементів модельованої системи;

- по-третє, відповідність моделі рівню дослідження, що дозволяє зробити висновки та узагальнення, що перевіряються експериментальним шляхом (Ягупов, 2003).

Моделювання - це процес створення ієрархії моделей, у яких освітній і виховний процес моделюється в різних аспектах і різними засобами. Моделювання педагогічних систем є однією з найважливіших задач сучасної освіти, оскільки зростає значимість проєктування й упровадження нових інноваційних технологій, що відповідають передовим теоретичним ідеям вітчизняної науки. У педагогічній науці метод моделювання обґрунтований у працях (Давидов,2003; Дахін, 2003; Штофф, 1966).

На основі аналізу наукових здобутків зазначених науковців можна виділити основні етапи педагогічного моделювання, що були застосовані під час побудови структурно-функціональної моделі формування комунікативної компетентності майбутніх офіцерів інженерних військ у процесі іншомовної підготовки.

Перший етап передбачає вивчення сутності модельованого педагогічного явища чи об'єкта у військовому ЗВО, виявлення закономірностей його функціонування та розвитку, визначення життєво важливих складових.

Другий етап педагогічного моделювання полягає у визначенні завдань моделювання. Власне на основі конкретизації завдань здійснюється вибір модельованих властивостей реального педагогічного явища чи об'єкта. 
На третьому етапі здійснювалося безпосереднє створення моделі формування комунікативної компетентності майбутніх офіцерів інженерних військ у процесі іншомовної підготовки, упровадження якої допоможе покращити навчально-професійну діяльність курсантів та інтенсифікувати освітній процес військових ЗВО.

Четвертий етап передбачає перевірку валідності структурнофункціональної моделі формування комунікативної компетентності майбутніх офіцерів інженерних військ у процесі іншомовної підготовки в дослідно-експериментальній роботі (Маслій, 2020).

Для побудови власної структурно-функціональної моделі варто дати визначення поняття «модель». Моделювання - це обов'язкова частина педагогічного дослідження, яка використовується для опису й дослідження різноманітних процесів, у тому числі інформаційних, нововведень, властивостей, а також закономірностей розвитку системи освіти, навчальних середовищ тощо (Копняк, 2015).

Структурна модель відображає графічно всі структурні властивості певного об'єкта (Копняк, 2015). Під функціональною моделлю розуміється така модель, яка надає можливість вивчити функціональні особливості певного процесу, а також визначати її значення у взаємозв'язку з усіма внутрішніми та зовнішніми елементами. Узагальнюючи дані тлумачення, дамо визначення структурно-функціональної моделі. Отже, під структурно-функціональною моделлю ми будемо розуміти модель, яка графічно відображає функціональні особливості структурних елементів певного процесу.

На основі проведеного аналізу й реально існуючої системи освітнього процесу в умовах проведення експерименту i, беручи до уваги цю класифікацію, нами була розроблена структурно-функціональна модель, що розглядається як цілісна система. Вона складається зі змістовно-цільового, процесуального, результативного блоків, пов'язаних між собою. Структурнофункціональна модель розглядається як сукупність закономірних, функціонально пов'язаних компонентів, складових певної цілісної системи. Компоненти (блоки) даної моделі розкривають внутрішню організацію (структуру) процесу формування соціокультурної компетенції курсантів, відповідають за адекватне відтворення взаємодії між елементами даного процесу й мають функціональне призначення: змістовно-цільовий компонент - функція визначення мети та конструктивно-змістовна; процесуальний компонент - процесуальна функція; результативний компонент - функція контролю й оцінки.

Компоненти структурно-функціональної моделі реалізуються з опорою на особистісний, діяльнісний, ціннісний, творчий та інноваційний підходи до 
освіти, які доводять загальні і значні педагогічні засоби формування комунікативної компетентності майбутніх офіцерів інженерних військ у процесі іншомовної підготовки. Усі компоненти структурно-функціональної моделі розташовуються послідовно, взаємно доповнюють і взаємобумовлюють один одного за рахунок функціонального призначення, складаючи при цьому цілісний процес формування комунікативної компетентності майбутніх офіцерів інженерних військ у процесі іншомовної підготовки. Кожен із названих блоків отримав змістове наповнення, виходячи з функцій і специфіки досліджуваного процесу. Змістовно-цільовий блок моделі передбачає постановку цілей і визначення завдань формування комунікативної компетентності майбутніх офіцерів інженерних військ. Цільовий компонент моделі орієнтує на досягнення мети - формування комунікативної компетеності курсантів - через вирішення завдань: формувати цілісну систему іншомовних професійних знань; розвивати практичні іншомовні професійні вміння та навички; формувати іншомовну професійну мотивацію; формувати іншомовний комунікативний досвід. Цільовий компонент моделі включає педагогічні принципи: інтегративності, професійної мобільності, мотивації, самоорганізації, раціонального поєднання колективних та індивідуальних форм, практичної та прикладної спрямованості навчання та загальнодидактичні.

у процесі вивчення психолого-педагогічної літератури щодо формування комунікативної компетентності майбутніх офіцерів визначено принципи, що визначають мету дослідження: об'єктивність, конкретність, науковість, діалектичність, детермінізм.

Принцип об'єктивності розглядає формування комунікативної компетентності майбутніх офіцерів як істинність, що ґрунтується на «розкритті тих методів, способів і прийомів, за допомогою яких досягається об'єктивно істинне знання про навколишній світ».

Принцип детермінізму проявляється взаємозв'язком професійної підготовки майбутніх офіцерів із формуванням у них комунікативної компетентності.

Принцип діалектичної логіки ґрунтується на відображенні в мисленні майбутніх офіцерів визначальних шляхів об'єктивного професійного розвитку.

Принцип істинності, який забезпечує адекватне відображення професійної діяльності (Ахметзянова, 2015). 
Принцип діяльності $€$ формою активності особистості, що передбачає цілеспрямоване формування комунікативної компетентності майбутнього офіцера.

Принцип конкретності в нашому випадку ґрунтується на використанні методів дедукції, індукції, інтеграції, синкретизації тощо.

Принцип науковості сприяє сформованості в курсантів систематизованого наукового світогляду, що проявляється у знаннях основних наукових понять, теоретичних положень, власного професійного становлення на основі інтеграції.

А також доповнили специфічними принципами, які сприяють процесу формування комунікативної компетентності майбутніх офіцерів інженерних військ. Розглянемо їх детальніше.

1. Принцип інтегративності, який забезпечується використанням міжпредметних зв'язків для поповнення змісту фундаментальних дисциплін прикладними задачами зі спеціальності в процесі навчання.

2. Принцип професійної мобільності, який означає таку побудову змісту іншомовної освіти, за якою фахівець швидко переключається з одного виду комунікації на іншу, і отримує не тільки традиційні знання, уміння та навички, але й оволодіває комплексом самоосвітніх компетентностей, застосовуючи сучасні методики пошуку науково-технічної інформації.

3. Принцип мотивації, який передбачає створення таких педагогічних умов, за яких курсант спроможний зайняти активну особистісну позицію і найбільш повною мірою розкритися не тільки як об'єкт навчальної діяльності, але і як суб'єкт.

4. Принцип самоорганізації, який означає, що в теперішніх умовах суспільству потрібні ініціативні та самостійні фахівці, здатні постійно вдосконалювати себе, виявляти готовність до швидкого оновлення знань, розширення навичок і вмінь, освоєння нових технологій.

5.Принцип раціонального поєднання колективних та індивідуальних форм і способів навчальної роботи передбачає застосовування різноманітних методів і форм навчальної діяльності під час проведення занять.

6. Принцип практичної та прикладної спрямованості навчання полягає в розумінні зв'язків і залежностей між пізнанням дійсності, наслідком якої $\epsilon$ теорія та практика. Під час проведення лекцій курсанти мають здобувати знання, необхідні для їх успішної професійної діяльності, а на практичних заняттях - навчитись ефективно діяти в умовах, що пов'язані з розв'язуванням прикладних задач спеціальності. 
Процесуальний блок структурно-функціональної моделі формування комунікативної компетентності майбутніх офіцерів у процесі іншомовної підготовки функціонально відображає:

- логіку й етапи формування комунікативної компетентності майбутніх офіцерів;

- організаційні форми (фронтально-групова, індивідуальна; плюрально-синергетична; практико зорієнтовані та інтерактивні форми організації освітньої діяльності тощо);

- методи (метод проєктів, ситуативний метод («кейс-стаді»), вирішення практико-орієнтованих соціокультурних завдань, ділові та рольові ігри).

Під час реалізації моделі нами зроблений акцент на активних методах навчання i практико-орієнтованих формах організації навчальної та позанавчальної роботи, на застосування гуманітарних педагогічних технологій (модульно-рейтингова, «кейс-стаді», проєктна діяльність, «портфоліо» тощо). В освітньому процесі військового закладу вищої освіти важливим є розвиток суб'єктної позиції, рефлексивності як відображення процесів самовираження й самопізнання курсанта. У процесуальний блок моделі включені педагогічні умови формування комунікативної компетентності майбутніх офіцерів інженерних військ: формування позитивної мотивації до оволодіння складниками комунікативної компетентності й ціннісних орієнтирів у власній самореалізації; використання інноваційних методів, форм та інформаційно-комунікаційних технологій у процесі підготовки офіцерів інженерних військ до іншомовної комунікації; організація самостійної роботи майбутніх офіцерів інженерних військ із використанням інформаційно-комунікаційних технологій.

Результативний блок моделі містить компоненти (мотиваційноціннісний, когнітивно-лінгвістичний, інформаційно-комунікаційний, поведінково-діяльнісний), критерії, відповідні їм показники та діагностичні засоби, що дозволяють виявляти динаміку даного процесу. 3 урахуванням комплексу виявлених критеріїв із метою диференціації курсантів за ступенем сформованості комунікативної компетентності розроблена шкала, що містить високий, достатній, репродуктивний, початковий рівні.

Особливістю структурно-функціональної моделі формування комунікативної компетентності майбутніх офіцерів $\epsilon$ те, що вона спрямована на фахову підготовку курсантів і являє собою архітектоніку взаємопов'язаних блоків. 
Таким чином, у розробленій структурно-функціональної моделі формування комунікативної компетентності майбутніх офіцерів відображені всі складові цього процесу: мета і завдання - принципи - технології - зміст суб'єкти діяльності - результат. Структурно-функціональна модель дозволяє вирішити наявне протиріччя між необхідністю формування комунікативної компетентності майбутніх офіцерів і недостатньою розробленістю теоретичного обґрунтування даного процесу. Включені в модель блоки взаємопов'язані і націлені на досягнення запланованого результату підвищення рівня сформованості формування комунікативної компетентності майбутніх офіцерів у процесі іншомовної підготовки.

Упровадження структурно-функціональної моделі здійснювалося у три етапи й охопило такі дисципліни освітньої програми підготовки курсантів: «Військово-спеціальна мовна підготовка» та «Іноземна мова за професійним спрямуванням».

На формувальному етапі експерименту під час вивчення дисциплін професійного спрямування курсанти експериментальних груп займалися за розробленою нами методикою навчання англійської мови та формування необхідних умінь, а курсанти контрольних груп продовжували навчання $з$ використанням традиційних методів.

Оскільки перед проведенням завершального етапу експерименту нами було визначено основні показники сформованості комунікативної компетентності майбутніх офіцерів інженерних військ та рівень сформованості їхнього словника фахової термінології, то наприкінці дослідження ми знову провели таке оцінювання. Результати перевірки продемонстрували суттєве підвищення показників за виокремленими критеріями в курсантів експериментальних груп, які навчалися з використанням методів активного навчання. Водночас, зміни показників сформованості визначених компонент комунікативної компетентності майбутніх офіцерів інженерних військ у контрольних групах були незначними.

Табличя 1

Результати визначення показників сформованості комунікативної компетентності майбутніх офіцерів інженерних військ формувального експерименту

\begin{tabular}{|c|c|c|c|c|c|c|c|c|c|}
\hline \multirow{3}{*}{ Компоненти } & \multirow{3}{*}{ Групи } & \multicolumn{8}{|c|}{ Рівні } \\
\hline & & \multicolumn{2}{|c|}{ Високий } & \multicolumn{2}{|c|}{ Достатній } & \multicolumn{2}{|c|}{ Середній } & \multicolumn{2}{|c|}{ Низький } \\
\hline & & $\%$ & $\Delta$ & $\%$ & $\Delta$ & $\%$ & $\Delta$ & $\%$ & $\Delta$ \\
\hline \multirow{2}{*}{$\begin{array}{l}\text { Мотиваційно- } \\
\text { ціннісний }\end{array}$} & $\mathrm{K} \Gamma$ & 7,50 & \multirow{2}{*}{30,0} & 20,00 & \multirow{2}{*}{20,83} & 67,50 & \multirow{2}{*}{$-45,83$} & 5,00 & \multirow{2}{*}{-5} \\
\hline & $\mathrm{E} \Gamma$ & 37,50 & & 40,83 & & 21,67 & & 0,00 & \\
\hline
\end{tabular}


Педагогічні науки: теорія, історія, інноваційні технології, 2020, № 10 (104)

\begin{tabular}{|c|c|c|c|c|c|c|c|c|c|}
\hline \multirow{2}{*}{$\begin{array}{l}\text { Когнітивно- } \\
\text { лінгвістичний }\end{array}$} & $\mathrm{K} \Gamma$ & 12,50 & \multirow{2}{*}{27,5} & 27,50 & \multirow{2}{*}{9,17} & 60,00 & \multirow{2}{*}{$-36,67$} & 0,00 & \multirow{2}{*}{0} \\
\hline & $\mathrm{E \Gamma}$ & 40,00 & & 36,67 & & 23,33 & & 0,00 & \\
\hline \multirow{2}{*}{$\begin{array}{l}\text { Інформаційно- } \\
\text { комунікаційний }\end{array}$} & KГ & 10,00 & \multirow{2}{*}{25,83} & 25,00 & \multirow{2}{*}{22,5} & 65,00 & \multirow{2}{*}{$-48,33$} & 0,00 & \multirow{2}{*}{0} \\
\hline & $\mathrm{E} \Gamma$ & 35,83 & & 47,50 & & 16,67 & & 0,00 & \\
\hline \multirow{2}{*}{$\begin{array}{l}\text { Поведінково- } \\
\text { діяльнісний }\end{array}$} & $\mathrm{K \Gamma}$ & 5,00 & \multirow{2}{*}{30,56} & 20,00 & \multirow{2}{*}{$\begin{array}{l}17,7 \\
8\end{array}$} & 62,50 & \multirow{2}{*}{$-35,83$} & 12,50 & \multirow{2}{*}{$-12,5$} \\
\hline & $\mathrm{E \Gamma}$ & 35,56 & & 37,78 & & 26,67 & & 0,00 & \\
\hline
\end{tabular}

За результатами, поданими в таблиці, можна стверджувати, що збільшився відсоток курсантів, які досягли високого та достатнього рівнів за кожним компонентом, а загалом їх кількість збільшилася на 46,39%. На дієвість розробленої структурної моделі вказує те, що зменшилася кількість курсантів на середньому й початковому рівнях.

Висновки. Отже, розглянуте обґрунтування структури і змісту структурно-функціональної моделі формування комунікативної компетентності майбутніх офіцерів інженерних військ дозволяє стверджувати, що запропонована модель $є$ динамічною системою, спрямованою на фахову підготовку курсантів, що являє собою архітектоніку взаємопов'язаних блоків. Упровадження їі в освітній процес підготовки майбутніх офіцерів інженерних військ показало позитивні результати дослідження.

Перспективи подальших наукових розвідок полягають $у$ вдосконаленні та розширенні методів та форм, що використовуються в освітньому процесі для формування комунікативної компетентності майбутніх офіцерів у процесі іншомовної підготовки.

\section{ЛІТЕРАТУРА}

Ахметзянова, А. Т. (2015). Структурно-функциональная модель формитрования социокультурной компетенции у студентов педагогических вузов Современные проблемы науки и образования, 3. Режим доступу: http://www.scienceeducation.ru/ru/article/ view? id $=20084$ (дата звернення: 15.08.2020) (Akhmetzianova, A. T. (2015). Structural and functional model of sociocultural competence formation in students of pedagogical universities Modern problems of science and education, 3. Retrieved from: http://www.scienceeducation.ru/ru/article/view? id=20084 (access date: 15.08.2020)).

Давыдов, В. П., Рахимов, О. Х. (2003). Теоретические и методические основы моделирования процесса профессиональной подготовки специалиста. Инновации в образовании, 2, 59-67 (Davydov, V. P., Rakhimov, O. Kh. (2003). Theoretical and methodical bases of modeling of process of professional training of the expert. Innovations in education, 2, 59-67).

Дахин, А. Н. (2003) Педагогическое моделирование: сущность, эффективность и ... неопределенность. Педагогика, 4, 21-27 (Dakhin, A. N. (2003). Pedagogical modeling: essence, efficiency and ... uncertainty. Pedagogy, 4, 21-27).

Галецький, С. (2020). Структура комунікативної компетентності майбутніх викладачів іноземних мов. Педагогічні науки: теорія, історія, інноваційні технології, 5-6, 24-37 (Haletskyi, S. (2020). The structure of communicative competence of future teachers of foreign languages. Pedagogical sciences: theory, history, innovative technologies, 5-6, 24-37). 
Елькина, О. Ю. (2007). Теоретическая модель подготовки будущего учителя к формированию продуктивного опыта младших школьников. Вестник Томского государственного педагогического университета. Серия: Педагогика, Вып. 7 (70), 23-27 (Elkina, O. Yu. (2007). Theoretical model of preparation of the future teacher for formation of productive experience of younger schoolchildren. Bulletin of the Tomsk state pedagogical university. Series: Pedagogy, Issue 7 (70), 23-27).

Копняк, Н. (2015). Моделювання й інтеграція сервісів хмаро орієнтованого навчального середовища. Київ: ЦП Компринт (Kopniak, N. (2015). Modeling and integration of cloud-based learning environment services. Kyiv: CP Komprint).

Кулаков, Ю. А., Коган, А. В., Пирогов, А. А. (2011). Разработка и моделирование процесса безопасной многопутевой передачи информации в мобильных сетях. Вісник Національного технічного університету України «Київський політехнічний інститут». Сер.: Інформатика, управління та обчислювальна техніка, Вип. 54, 145-149 (Kulakov, Yu. A., Kogan, A.V., Pirogov, A.A. (2011). Development and modeling of the process of secure multi-way transmission of information in mobile networks Bulletin of the National Technical University of Ukraine "Kyiv Polytechnic Institute". Series: Informatics, M anagement and Computer Engineering, Vol. 54, 145-149).

Маслій, О. М. (2020). Теоретичні і методичні основи професійної підготовки майбутніх офріцерів ракетно-артилерійського озброєння у вищих військових навчальних закладах (дис. ... д. пед. н.: 13.00.04). Х. (Maslii, О. М. (2020). Theoretical and methodological bases of professional training of future missile and artillery officers in higher military education institutions (DSc thesis)).

Монахов, В. М. (2001). Педагогическое проектирование - современный иструментарий дидактических исследований. Школьные технологии, 5, 75-89 (M onakhov, V. M. (2001). Pedagogical design - a modern toolkit of didactic research. School technologies, 5, 75-89).

Москаленко, А. М. (2001). Розвиток умінь педагогічного спілкування в системі післядипломної освіти (дис. ... к. пед. н.: 13.00.04). К. (Moskalenko, А. М. (2001). Development of skills of pedagogical communication in the system of postgraduate education (PhD thesis)).

Панфилов, М. А. (2005). Знаково-символическое моделирование учебной информации в вузе. Педагогика, 9, 51-56 (Panfilov, M. А. (2005). Sign-symbolic modeling of educational information in high school. Pedagogy, 9, 51-56).

Філософський енциклопедичний словник (2002). Київ: Абрис (Philosophical Encyclopedic Dictionary (2002). Kyiv: Abris).

Штофф, В. А. (1966). Моделирование и философия. М., Л.: Наука (Stoff, W. А. (1966). Modeling and philosophy. M., L.: Science).

Ягупов, В. (2003). Моделювання навчального процесу як педагогічна проблема. Неперервна професійна освіта: теорія і практика, 1, 28-37 (Yagupov, V. (2003). Modeling of the educational process as a pedagogical problem. Continuing professional education: theory and practice, 1, 28-37).

\section{PEЗЮME}

Нанивская Лидия. Структурно-функциональная модель формирования коммуникационной компетентности будущих офицеров инженерных войск: анализ результатов.

В статье рассмотрены теоретические вопросы построения структурнофункциональной модели фрормирования коммуникативной компетентности будущих офицеров инженерных войск в процессе иноязычной подготовки. 
Использованы данные психолого-педагогических источников и проведенных научных исследований по определенной теме. Это дало возможность выделить составляющие структурно-функциональной модели: содержательно-целевой; процессуальный; результативный. Экспериментальная работа по проверке действенности структурно-функциональной модели в образовательном процессе высших военных заведений осуществлялась в три этапа и охватила дисциплины образовательной программы подготовки курсантов: «Военно-специальная языковая подготовка» и «Иностранный язык по профессиональному направлению».

Ключевые слова: иноязычная подготовка, будущие офицеры, модель, компоненты, организационно-педагогические условия, методы, метод проектов, ситуативный метод.

\section{SUMMARY}

Naniska Lidta. Structural-functional model of communicative competence formation of future officers of engineering troops: results analysis.

The article considers theoretical issues of building a structural and functional model of the formation of communicative competence of future officers of engineering troops in the process of foreign language training. The paper used data from psychological and pedagogical sources and conducted research on the formation of communicative competence of future officers of engineering troops in the process of foreign language training. A comparative method of analysis was used. This made it possible to distinguish the components of the structural-functional model of formation of communicative competence of future officers of engineering troops in the process of foreign language training: contenttarget component - the function of goal setting and constructive-content; procedural component - procedural function; resultative component - the function of control and evaluation. The components of the structural-functional model are implemented based on personal, activity, value, creative and innovative approaches to education, which prove general and significant pedagogical means of the communicative competence formation of future officers of engineering troops in foreign language training.

Experimental work to verify the effectiveness of the structural-functional model in the educational process of higher military institutions was carried out at three stages and covered the following disciplines of the educational program for cadets: "Special military language training" and "Foreign language for professional purposes".

At the molding stage of the experiment, while studying the disciplines of professional orientation, the cadets of the experimental groups studied according to the designed methodology of English teaching and necessary skills developing, and the cadets of the control groups continued their studies using traditional methods.

Since before the final stage of the experiment it was determined the main indicators of the formation of communicative competence of future officers of engineering troops and the formation level of their professional training vocabulary, then at the end of the study it was conducted such an assessment too. The results of the test showed a significant increase in the selected indicators in the cadets of the experimental groups who studied using the methods of active learning. At the same time, changes in the indicators of formation of certain components of communicative competence of future officers of engineering troops in the control groups were insignificant.

Key words foreign language training, future officers, model, components, organizational-pedagogical conditions, methods, project method, situational method. 